\title{
Towards a Neo-Apartheid System of Governance in Latin America -Implications for the Community Informatics Guild
}

\author{
Scott S. Robinson \\ Universidad Metropolitana, México, D.F. < ssr@laneta.apc.org >
}

\begin{abstract}
Governance today is being reconfigured by the evolving global demand for unskilled labor in the North and elite intransigence linked to limited capital inflows in the South. The emerging profile is one of dual economies wherein the wealthy dominate decision-making systems and strategic sectors while struggling to sustain a return on their investments, and the poor either emigrate or administer meager resources in the informal sector of their respective national economies. Remittance transfers now sustain this growing corpus of diaspora communities throughout the region.
\end{abstract}

This grim scenario is now widespread in the context of States under reconfiguration, moving toward a "ritual and virtual fiction" of e-governance orchestrated by shrewd and skilled elites who have responded adaptively to the challenges that information technologies represent to their historical leadership and hegemony while astutely orchestrating an "apertura democratica" that is more form than substance. Latin America with its pronounced income distribution inequities is the region where this process is quite visible. And its current intensification should belie illusions about enhancing democracy via top down, "government as online citizen administrative chores and tax payment systems" and kindred supply side information technology initiatives. E-government programs in this context may only exacerbate the current class and ethnic polarities.

Students and practitioners of "community informatics" need take this scenario into account when either designing research protocols or consulting with activist ICT non-governmental organizations who are committed to a rustic, ingenuous "better connectivity=enhanced democratic culture" strategy. The latter today too often ignores the power of national elites who have configured their regulatory regimes to favor quasi-monopolistic market dominance in cahoots with foreign IT hardware and software interests. At the same time, this innocence fails to lead to a critical perspective on the design and impact of official connectivity programs too often tailored without critical, public input in the Ministries' chambers and much attuned to the interests of corporate hardware and proprietary software suppliers.

Today, many government subsidized connectivity projects languish in schools, libraries and public health centers where community "buy-in" is scarce, training limited, maintenance infrequent and content often irrelevant to the needs and aspirations of the local, young IT consumers. This growing population has already been weaned at the town or village cybercafe, a regional network of mom and pop connectivity shops whose self-sustaining human and technical resources are largely ignored by the State programs. This profile of the Latin American connectivity and ineffective use pattern, suggests community informatics in this region of the South requires distinctions and caveats in any general arguments meant to apply globally, an urgent priority for forthcoming conferences on the topic.

As we slouch toward the second World Summit on the Information Society (Tunis, November 2005), Latin American States emerge from a lengthy and costly reconfiguration of public assets. Now largely privatized, these resources allow national and regional elites and capital groups (plus their foreign allies) to sustain their historical controls via modern IT-anchored mechanisms, whereby partnerships with "privatized" public entitites and foreign capital partners effectively concentrate power in the key media, telecommunications and energy sectors of the respective national economies; such societies already being dramatically polarized between rich and poor. As a result, the emerging privatized Latin American State may be a ritualized fiction that sustains a democratic drama while power is increasingly concentrated and constrains any radical democratizing process (recent events in Venezuela are indicative). 
In these States there is no civil service, little or no due process, limited transparency re public contracts and government budget disbursements, an elite-controlled media and telecommunications sectors, and the remittance economy has become the social safety net for the poor. The scale of the latter today permits these same elites to applaud the growing remittance flows while attenuating pressures on national social service budgets whereby "the poor appear to be able to pay their own way". Add to this the discourse about decentralized municipal authority and it is not difficult to perceive the ruse that camouflages the concentration of effective power in these countries. Plans for the delivery of key government services via online portals may portend a "virtual State" where the programming protocols of the servers remain in the discretionary hands of a few. This is not the model of e-governance some of us may have in mind. 